\title{
Structural assessment of Iranian scholarly journals
}

\author{
Mohammad Reza Ghane \\ Regional Information Center for Science and Technology, RICeST \\ Research Department of Evaluation and Collection Development \\ Jam-e-Jam Ave, Jomhouri Blvd, Shiraz - IRAN, 71946-94171 \\ e-mail: ghane@ricest.ac.ir
}

\begin{abstract}
Scholarly journals should adhere to quantitative and qualitative standards for their continuing existence and acceptance by the scientific community, making them eligible for application and indexation in international databases. Concerning this, the journal editorial board would be held accountable for any flaws in publication standards. Obviously, improving standards causes perpetual scholarly communication between authors and journal editors as well as publishers, accreditation and quality assurance, and research finding dissemination. The objective of this study is to assess the status of 359 scientific journals in Iran with regards to their commitment to publication standards. The findings depict journals' strengths and weaknesses in relation to the editorial profile, instant references, layout quality, exclusive features, academic profile, and miscellaneous features.
\end{abstract}

Keywords: Academic journal assessment; Layout quality; Editorial board; Publication frequency; Peer-reviewed journals.

\section{INTRODUCTION}

Scholarly publication is the final stage of research, and scholarly journals are expected to provide a detailed and permanent record of research findings. They are used to bridge the gap between the latest research and scientific communities within a field and to assess intellectual capital. Because journal publications form the basis for both new research and the application of findings, they can affect not only the research community but also, indirectly, society at large. Authors, users, and distributors play an important role in scholarly communication life cycle. Since the beginning of scholarly journal publishing in the mid of seventeenth century, quality control was considered by all stakeholders of scholarly communication. The authors have a responsibility to ensure that their publications are "honest, clear, accurate, complete and balanced, and should avoid misleading, selective or ambiguous reporting" (Wager and Kleinert 2010).

On the other hand, journal editors have responsibilities for ensuring the standard of the journal publication. Standardization leads to meet the needs of the scholarly community and improve the quality and accessibility of the journals (MEDLINE ${ }^{\circledR}$ Journal Selection Fact Sheet 2014). Abstracting and Indexing Services (A\&I) as well as citation indexing agencies exert the standardizing through their journal selection policy. Addressing the quality and editorial criteria, these services are helpful and play a crucial role for journal visibility (PKP 2015). To achieve this purpose, journal indexing in the right database is essential as the visibility of scholarly journals is viewed in terms of its index status by national or universal indexing databases (Abrizah et al. 2013). To provide a wider reach to the latest research findings, A\&l services and citation databases selection policy paved the way, against a 
number of strict selection criteria for journal inclusion. These criteria are mostly quality ones and differ from one database to another. In this context, samples are Educational Resource Information Center (ERIC), Medical Literature Analysis and Retrieval System Online (MEDLINE), Library and Information Science Abstract (LISA), Thomson Reuters' Web of Knowledge, Elsevier's SCOPUS, and Islamic World Science Citation Center (ISC). All criteria push journals towards standardization and internationality.

Evidently, journal editors play a crucial role at the centre of journal publishing and a sophisticated editorial board serves as a critical factor for the structure and quality of a journal (Hill 2008). To improve the journal quality and accessibility, well-established editors consider basic journal standards, such as publication frequency, references accuracy, data integrity, abstract and keywords, layouts, and contributors' personal information as important criteria in publication. There are a few elements that help to set up a qualified journal. In relation to the responsibilities of a scientific journal, i.e. archiving, registration, dissemination and certification, journal editors should consider editorial profile, instance references, layout quality, exclusive features, academic profile, in parallel with content, to maintain the impact and prestige of their journal in the competitive environment (Priem and Hemminger 2012). To this aim journal standardization is necessary and some useful guidelines are freely available such as those published by ICMJE (2015) and COPE (2011).

Unique features such as timeliness, friendly submission systems, accessibility to journal content (Yang 2014) and remove the language barrier (Bordons and Gómez 2004) are important in making journal reputation and recognition. Bordons and Gómez (2004) stated that journal internationality is not limited to the language or the country of origin. Other factors such as international editorial boards, international contributors, and audiences affect journal improvement internationally. Since access to the latest research findings is important for scientific societies, journal editors endeavor to attract prolific authors and reviewers as well as international readership.

Journal publishers' effort in providing more standard in journal publishing process, leads to more exposure for the journal content. Publication frequency as a standard characteristic of journal is a matter of importance to indexing databases, especially citation indexes. Xue$\mathrm{Li}$, Rui-Yuan and Mei-Ying (2012) found that there is a positive correlation between publication frequency and journal impact factor (JIF). They concluded that with the increase of publication frequency, the JIF increases. Ackermann (2006) showed that the growth or decline in journal publication frequency leads to fail epidemic literature growth in the scientific journals. It is noteworthy that keywords are a crucial part of scholarly writing (Sharma and Mediratta 2002). Considering keywords in Persian and English, they boost the relevant document retrieval from online databases. Sotuedeh, Razmjoo and Zare (2009) investigated Iranian electronic journals based on six main criteria i.e. instant references, author guidelines, way of access, content accessibility, journal specifications (ISSN, journal English title, place of publication), and editorial profile. They concluded that more than three-quarter of journals are accessed over the Internet and half of the journals included six aforementioned criteria.

Thus, editorial board members are required to develop journal publication policies. Editors control the journal publication with the help of editorial board members to ensure the quality content (Graf et al. 2007). The composition of editorial board exerts journal standards and promotes journal networking. Developing author and peer review guidelines is one of the main task of editorial board to make readers and authors aware of the pool of knowledge in their respective area of study. 
It is obvious that the physical format of a journal based on specific publication features is as important as the journal content. In this context, journal features investigations are a matter of noteworthy and cause journals or authors to increase their visibility and prestige. In this study the author focuses on the structural aspect, rather than content and believes that the former factor contributes to improve journal quality.

\section{OBJECTIVES AND METHOD}

The overall objective of this study is to determine the publication standard of Iranian academic journals in relation to a set of features considered as crucial by the committees of academic journals at the Ministry of Science, Research and Technology (MRST) and Ministry of Health and Medical Education (MOHE) Iran. These two committees assess academic journals based on the following important elements:

a) editorial profile (journal publication frequency, managing editor, editor-in-chief, editorial boards, editors, translators),

b) instant references (postal address, phone number, e-mail, and website),

c) layout quality (page design, images, photos, tables, graphs),

d) exclusive features (general guidelines, multiple authorship, international coauthorship, editorial modification, manuscript preparation and submission commitment),

e) academic profile (authors' academic degree and rank, authors' affiliation),

f) miscellaneous features (year published, editorials, submission and acceptance date, Persian and English abstracts including keywords).

The following research questions are posed:

a) To what extent are journals committed to their composition of editorial profile?

b) How important are the presence of instant references to journals?

c) What are the elements of journal physical layout considered?

d) What are the elements of journals' exclusive features included?

e) Are journals concerned about authors' academic profiles?

A survey was conducted to address the overall objective and answer the research questions pose. To evaluate the extent to which the journals support publication standards, a checklist consisting of 17 questions and 76 sub questions was developed. A newly created checklist for the assessment of journals elaborated on the principles of the evidence-based criteria was used for analysis. The checklist was categorized into six important elements as delineated earlier.

The population of the study consists of 1377 academic journals owned by MRST and MOHE, covered by the Iran journal database (http://en.ricesr.ac.ir) of all Iranian peerreviewed journals, published in Persian and English Languages. Journals in five broad disciplines were chosen, i.e., Social Sciences and Humanities, Medical Sciences, Engineering, Agriculture and Veterinary, and Basic Sciences. Using systematic random sampling, the sample size was 359 (confidence level $=95 \%$, confidence interval $=4.45$ ).

Using this database, data of academic journals were exported to Microsoft Excel spreadsheet and all sections in the sample journals were carefully scrutinized. The study took into account the form and structure of journals within the publication. The quality of 
content is not included in this study considering the validity and originality of the articles to the scope and coverage of the journal.

A total of 359 academic journals were benchmarked based on the checklist. More than three-quarter of the journals were published by university press, and this indicated that the universities are the main publishers. A total of 289 journals $(80.5 \%)$ used ISSN code in practicing in relation with journals content. ISSN is a matter of importance to A\&I services, citation databases and ultimately serve journal retrieval. A total of 252 journals (70.2\%) used subscription order form to the print and online versions.

More than half of the journals $(187,52.1 \%)$ neglected the number of copies printed (pressrun). This study showed that more than $60 \%$ of journals publish an issue with page size of $<100$ to 150 . The breakdowns are presented in Table 1 . In addition to the economic importance of the number of pages published in journals, studies have shown the impact of the article length on future citations; however this is dependent on the disciplines (Falagas et al. 2013; Mavros et al. 2013). Ball (2008) reported a positive association between the article length and the article citations.

Table 1: Journal Page Size in Different Subject Categories

\begin{tabular}{|c|c|c|c|c|c|c|c|c|c|}
\hline \multirow{2}{*}{$\begin{array}{l}\text { Page size } \\
\text { Subject category }\end{array}$} & \multicolumn{2}{|c|}{$\leq 100$} & \multicolumn{2}{|c|}{$101-150$} & \multicolumn{2}{|c|}{$151-200$} & \multicolumn{2}{|c|}{$>200$} & \multirow[b]{2}{*}{ Total } \\
\hline & $\begin{array}{l}\text { Freq. } \\
\text { Percent } \\
\end{array}$ & $\begin{array}{l}\% \text { within } \\
\text { the group }\end{array}$ & $\begin{array}{l}\text { Freq. } \\
\text { Percent } \\
\end{array}$ & $\begin{array}{l}\% \text { within } \\
\text { the group }\end{array}$ & $\begin{array}{l}\text { Freq. } \\
\text { Percent }\end{array}$ & $\begin{array}{l}\% \text { within } \\
\text { the group }\end{array}$ & $\begin{array}{l}\text { Freq. } \\
\text { Percent }\end{array}$ & $\begin{array}{l}\% \text { within } \\
\text { the group }\end{array}$ & \\
\hline $\begin{array}{l}\text { Social Sciences and } \\
\text { Humanities }\end{array}$ & $\begin{array}{r}8 \\
6.2 \% \\
\end{array}$ & 5 & $\begin{array}{r}43 \\
48.3 \% \\
\end{array}$ & 27 & $\begin{array}{r}49 \\
70 \% \\
\end{array}$ & 30.8 & $\begin{array}{r}59 \\
83.1 \% \\
\end{array}$ & 37.1 & 159 \\
\hline Medical Sciences & $\begin{array}{r}73 \\
56.6 \% \\
\end{array}$ & 77.7 & $\begin{array}{r}16 \\
17.8 \% \\
\end{array}$ & 17 & $\begin{array}{r}5 \\
7.1 \% \\
\end{array}$ & 5.3 & - & - & 94 \\
\hline Engineering & $\begin{array}{r}33 \\
25.6 \% \\
\end{array}$ & 71.7 & $\begin{array}{r}9 \\
10.1 \% \\
\end{array}$ & 19.6 & $\begin{array}{r}4 \\
5.7 \% \\
\end{array}$ & 8.7 & - & - & 46 \\
\hline $\begin{array}{l}\text { Agriculture and } \\
\text { Veterinary }\end{array}$ & $\begin{array}{r}6 \\
4.7 \% \\
\end{array}$ & 15 & $\begin{array}{r}15 \\
16.9 \% \\
\end{array}$ & 37.5 & $\begin{array}{r}8 \\
11.5 \% \\
\end{array}$ & 20 & $\begin{array}{r}11 \\
15.5 \% \\
\end{array}$ & 27.5 & 40 \\
\hline Basic Sciences & $\begin{array}{r}9 \\
6.9 \%\end{array}$ & 45 & $\begin{array}{r}6 \\
6.7 \%\end{array}$ & 30 & $\begin{array}{r}4 \\
5.7 \% \\
\end{array}$ & 20 & $\begin{array}{r}1 \\
1.4 \%\end{array}$ & 5 & 20 \\
\hline Total & 129 & 35.9 & 89 & 24.8 & 70 & 19.5 & 71 & 19.8 & 359 \\
\hline
\end{tabular}

\section{FINDINGS}

\section{Journals' commitment to the composition of editorial profile}

A team of experienced managing editors can always provide publication services as effectively and efficiently as possible. The journal editorial structure lists the names and positions of the different editorial board members. An analysis of the editorial structure indicates the presence of journal proprietor in 94.7 percent (340 titles) journals. Journals considered listing the managing editor $(356,99.2 \%)$, editor-in-chief $(98.6 \%)$, editorial boards $(354,95.8 \%)$, but somehow less regarded listing the editors $(274,76.3 \%)$ and translators $(137,38.2 \%)$. Based on the Chi-Square test in Table 2, there is a significant relationship between journals' commitment and each component of editorial profile $(P<0.05)$. The greater the Chi-Square, the stronger the relationship, the results uncover that journals are more sensitive to have managing editor $\left(\chi^{2}=347.1\right)$, editor-in-chief $\left(\chi^{2}=\right.$ 339.3), editorial boards $\left(\chi^{2}=301.5\right)$, and journal proprietor $\left(\chi^{2}=287\right)$ than editors $\left(\chi^{2}=\right.$ 99.5) and translators $\left(\chi^{2}=20.1\right)$. For all statistical tests a P-value of less than 0.05 was considered to be significant. 
Table 2: Chi-Square Test of Editorial profile

\begin{tabular}{|l|c|r|r|r|r|r|}
\hline & $\begin{array}{c}\text { Journal } \\
\text { proprietor }\end{array}$ & $\begin{array}{c}\text { Managing } \\
\text { editor }\end{array}$ & $\begin{array}{c}\text { Editor-in- } \\
\text { chief }\end{array}$ & $\begin{array}{c}\text { Editorial } \\
\text { boards }\end{array}$ & Editors & Translators \\
\hline Chi-Square & $287.022^{\mathrm{a}}$ & $347.100^{\mathrm{a}}$ & $339.279^{\mathrm{a}}$ & $301.507^{\mathrm{a}}$ & $99.501^{\mathrm{a}}$ & $20.125^{\mathrm{a}}$ \\
$\mathrm{df}$ & 1 & 1 & 1 & 1 & 1 & 1 \\
Asymp. Sig. & .000 & .000 & .000 & .000 & .000 & .000 \\
\hline
\end{tabular}

a. 0 cells $(.0 \%)$ have expected frequencies less than 5 . The minimum expected cell frequency is 179.5 . $\mathrm{P}<0.05$

Based on publication frequency, most journals are published quarterly $(71.7 \%, 258)$, followed by biannually $(20.6 \%, 74)$, and bimonthly $(5.8 \%, 21)$. Four journals $(1.1 \%)$ are published monthly (with twelve issues per year) and only two is published triennially (three issues per year). Table 3 presents these findings.

There are five categories in relation to journals publication frequency (Table 3). About 72 percent of journals ( 258 titles) are quarterly. Biannual journals are in the second place with 74 journals. Bimonthly (21), monthly (4), and triennial (2) journals are in the third to fifth place, respectively.

Table 3: Journals Publication Frequency

\begin{tabular}{l||r||r}
\hline \multicolumn{1}{c||}{ Publication Frequency } & Frequency & Percentage \\
\hline \hline Quarterly & 258 & 71.9 \\
\hline \hline Biannual & 74 & 20.6 \\
\hline \hline Bimonthly & 21 & 5.8 \\
\hline \hline Monthly & 4 & 1.1 \\
\hline \hline Triennial & 2 & 0.6 \\
\hline \hline Total & 359 & 100 \\
\hline \hline
\end{tabular}

\section{Presence of Instant References}

Getting quick answers to the most pressing questions about the journals is important to authors and readers. Postal address, phone number, e-mail $(98.9 \%, 93.6 \%$, and $91.9 \%$, respectively) are regarded as a valid form of contacts, but journals sampled paid less attention to website URLs (72.4\%). To identify the relationship between components of academic profile and instant references, cross tabulation and Chi-Square Test were used. Results showed that there is a relationship between all components of two categories $(P<0.05)$ except for translator and post address $(P>0.05)$. The breakdowns are shown in Table 5.

Table 5: Chi Square Test for Association between Academic Profile and Instant References

\begin{tabular}{l|c|c|c|c}
\hline \hline Academic profile & Website & Postal address & Phone number & Email \\
\hline \hline Journal proprietor & $\chi^{2}=72.385$ & $\chi^{2}=52.687$ & $\chi^{2}=293.076$ & $\chi^{2}=228.289$ \\
\hline \hline Managing editor & $\chi^{2}=7.945^{*}$ & $\chi^{2}=268.494$ & $\chi^{2}=44.195$ & $\chi^{2}=34.426$ \\
\hline \hline Editor-in-chief & $\chi^{2}=13.317$ & $\chi^{2}=286.391$ & $\chi^{2}=74.075$ & $\chi^{2}=57.00$ \\
\hline \hline Editorial boards & $\chi^{2}=41.112$ & $\chi^{2}=92.767$ & $\chi^{2}=228.686$ & $\chi^{2}=178.133$ \\
\hline \hline Editors & $\chi^{2}=292.483$ & $\chi^{2}=13.039$ & $\chi^{2}=79.216$ & $\chi^{2}=101.697$ \\
\hline \hline Translators & $\chi^{2}=84.358$ & $\chi^{2}=2.496^{*}$ & $\chi^{2}=15.165$ & $\chi^{2}=19.469$ \\
\hline \multicolumn{1}{c}{$\mathrm{P}<0.05, \mathrm{df}=1 \quad{ }^{*} \mathrm{P}>0.05$}
\end{tabular}




\section{Elements of Journal Physical Layout Considered}

One aspect of journal physical layout considered is the page design as well as presence of tables and illustrations such as images, photos, and graphs. High-quality layout attracts the readers and helps them in understanding the research process and outputs. Inconsistency in different aspects of page design will result a negative perception of a journal's quality (O'Moore-Klopf 2010). Each journal publishes with a different layout style, and the consistency of its layout is important to the readers. The horizontal and vertical position of elements in pages such as publication date, volume, issue, article title, and journal title and their balance on a page is the jurisdiction of the editorial office. The findings of the study uncovered that 98.3 percent (353) of journals have maintained the layout consistency. Consistency in terms of information on volume and issue was less considered. Figure 1 details the findings.

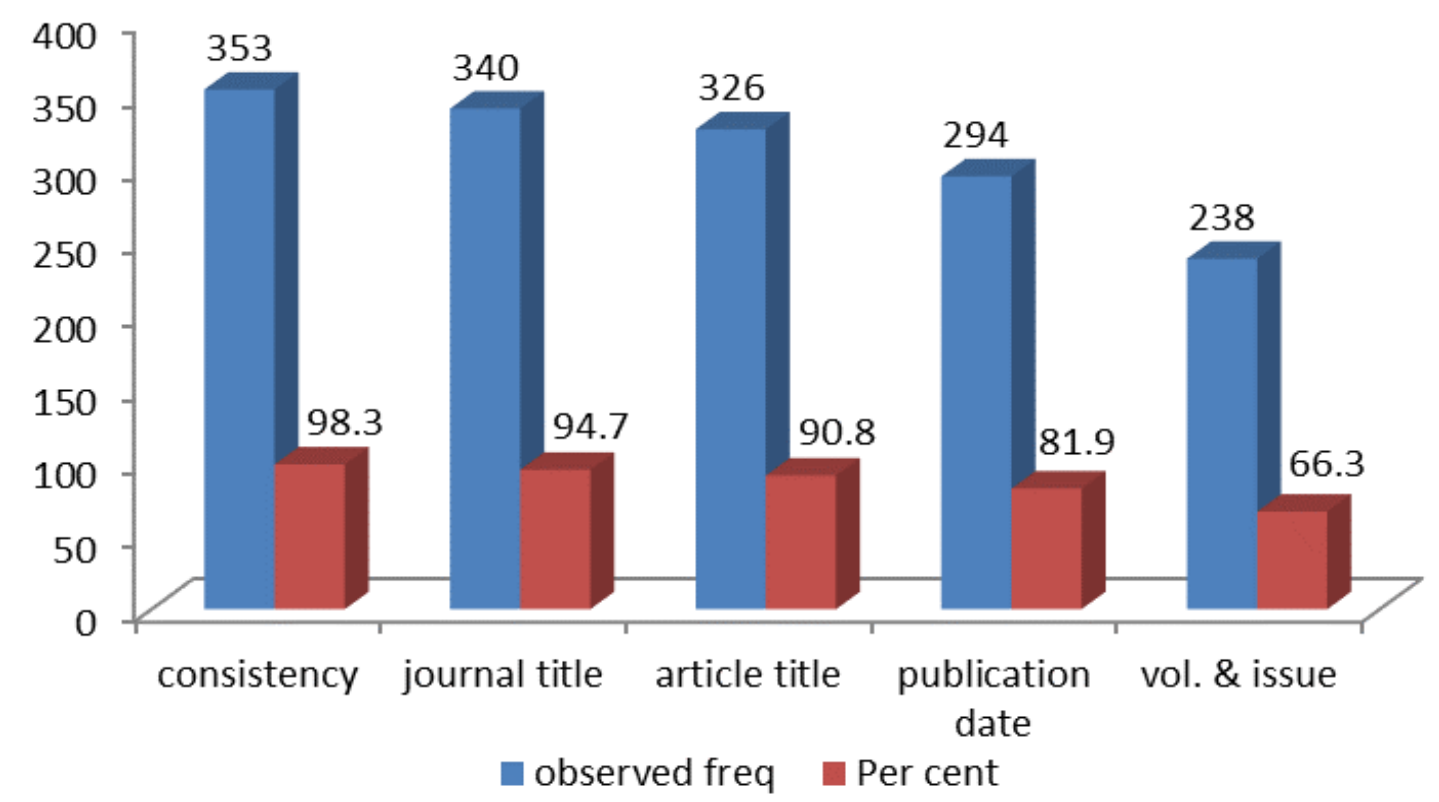

Figure 1: Presence of Journal Physical Layout Elements

\section{Elements of Journal Exclusive Features}

Although the elements that denote journal publishing quality are important, exclusive features such as information on general guidelines, multiple authors, international coauthorship, peer review process, manuscript submission guidelines, and submission commitments are of eminence. In general, the study found that the journals are more committed to having general guidelines $(94.2 \%, 338)$ and multiple authors $(92.8 \%, 333)$. Manuscript submission guidelines $(78.8 \%, 283)$ and peer review process $(72.4 \%, 260)$ are of third and fourth importance to the journals. Editors have low tendency to include submission commitments in the journal $(47.1 \%, 169)$. Since Persian language is in the list of the less-spoken languages in the world, having 50 to 100 million native speakers (Wikipedia 2015), the low percentage of 5.3 percent (19) of journals publishing articles with international co-authorship is expected. A detailed investigation based on different subject disciplines in relation to the exclusive features is presented in Table 6. 
Table 6: Information on Journal Exclusive Features based on Subject Disciplines

\begin{tabular}{|c|c|c|c|c|c|c|c|c|c|c|}
\hline $\begin{array}{l}\text { Subject } \\
\text { disciplines }\end{array}$ & \multicolumn{2}{|c|}{$\begin{array}{c}\text { Social Sciences \& } \\
\text { Humanities }\end{array}$} & \multicolumn{2}{|c|}{ Medical Sciences } & \multicolumn{2}{|c|}{ Engineering } & \multicolumn{2}{|c|}{$\begin{array}{l}\text { Agriculture \& } \\
\text { Veterinary }\end{array}$} & \multicolumn{2}{|c|}{ Basic Sciences } \\
\hline \multirow{2}{*}{$\begin{array}{l}\text { General } \\
\text { guidelines }\end{array}$} & with & w/out & with & w/out & with & w/out & with & w/out & with & w/out \\
\hline & $\begin{array}{c}144 \\
(40 \%)\end{array}$ & $\begin{array}{c}15 \\
(4.2 \%)\end{array}$ & $\begin{array}{c}94 \\
(26.2 \%)\end{array}$ & - & $\begin{array}{c}41 \\
(11.4 \%)\end{array}$ & $\begin{array}{c}5 \\
(1.4 \%)\end{array}$ & $\begin{array}{c}40 \\
(11.1 \%)\end{array}$ & - & $\begin{array}{c}19 \\
(5.3 \%)\end{array}$ & $\begin{array}{c}1 \\
(0.28 \%)\end{array}$ \\
\hline $\begin{array}{l}\text { Multiple } \\
\text { authors }\end{array}$ & $\begin{array}{c}157 \\
(43.7 \%) \\
\end{array}$ & $\begin{array}{c}2 \\
(0.56 \%) \\
\end{array}$ & $\begin{array}{c}78 \\
(21.7 \%) \\
\end{array}$ & $\begin{array}{c}16 \\
(4.5 \%) \\
\end{array}$ & $\begin{array}{c}40 \\
(11.1 \%) \\
\end{array}$ & $\begin{array}{c}6 \\
(1.7 \%) \\
\end{array}$ & $\begin{array}{c}40 \\
(11.1 \%) \\
\end{array}$ & - & $\begin{array}{c}18 \\
(5.0 \%) \\
\end{array}$ & $\begin{array}{c}2 \\
(0.56 \%) \\
\end{array}$ \\
\hline $\begin{array}{l}\text { Submission } \\
\text { guidelines }\end{array}$ & $\begin{array}{c}111 \\
(31 \%)\end{array}$ & $\begin{array}{c}48 \\
(13.4 \%)\end{array}$ & $\begin{array}{c}88 \\
(24.5 \%)\end{array}$ & $\begin{array}{c}6 \\
(1.7 \%)\end{array}$ & $\begin{array}{c}32 \\
(8.9 \%)\end{array}$ & $\begin{array}{c}14 \\
(3.9 \%)\end{array}$ & $\begin{array}{c}36 \\
(10.0 \%)\end{array}$ & $\begin{array}{c}4 \\
(1.1 \%)\end{array}$ & $\begin{array}{c}16 \\
(4.5 \%)\end{array}$ & $\begin{array}{c}4 \\
(1.1 \%)\end{array}$ \\
\hline $\begin{array}{l}\text { Peer review } \\
\text { process }\end{array}$ & $\begin{array}{c}114 \\
(31.8 \%)\end{array}$ & $\begin{array}{c}45 \\
(12.5 \%)\end{array}$ & $\begin{array}{c}87 \\
(24.2 \%)\end{array}$ & $\begin{array}{c}7 \\
(1.9 \%)\end{array}$ & $11(3 \%)$ & $\begin{array}{c}35 \\
(9.7 \%)\end{array}$ & $\begin{array}{c}36 \\
(10.0 \%)\end{array}$ & $\begin{array}{c}4 \\
(1.1 \%)\end{array}$ & $\begin{array}{c}12 \\
(3.3 \%)\end{array}$ & $\begin{array}{c}8 \\
(2.2 \%)\end{array}$ \\
\hline $\begin{array}{l}\text { Submission } \\
\text { commitments }\end{array}$ & $\begin{array}{c}41 \\
(11.4 \%)\end{array}$ & $\begin{array}{c}118 \\
(32.9 \%)\end{array}$ & $\begin{array}{c}79 \\
(22 \%)\end{array}$ & $\begin{array}{c}15 \\
(4.2 \%)\end{array}$ & $\begin{array}{c}32 \\
(8.9 \%)\end{array}$ & $\begin{array}{c}14 \\
(3.9 \%)\end{array}$ & $\begin{array}{c}3 \\
(0.8 \%)\end{array}$ & $\begin{array}{c}37 \\
(10.3 \%)\end{array}$ & $\begin{array}{c}14 \\
(3.9 \%)\end{array}$ & $\begin{array}{c}6 \\
(1.7 \%)\end{array}$ \\
\hline $\begin{array}{l}\text { International } \\
\text { co- authorship }\end{array}$ & $\begin{array}{c}7 \\
(1.9 \%)\end{array}$ & $\begin{array}{c}152 \\
(42.3 \%)\end{array}$ & $\begin{array}{c}1 \\
(0.28 \%)\end{array}$ & $\begin{array}{c}93 \\
(25.9 \%)\end{array}$ & $\begin{array}{c}4 \\
(1.1 \%)\end{array}$ & $\begin{array}{c}42 \\
(11.7 \%)\end{array}$ & $\begin{array}{c}1 \\
(0.28 \%)\end{array}$ & $\begin{array}{c}39 \\
(10.7 \%)\end{array}$ & $\begin{array}{c}6 \\
(1.7 \%)\end{array}$ & $\begin{array}{c}14 \\
(3.9 \%)\end{array}$ \\
\hline
\end{tabular}

\section{Presence of Authors' Academic Profiles}

In addition to the standard editorial convention identified earlier, higher education institutes in Iran consider the academic profile of their researchers (i.e. information on academic degree, rank, and affiliations) to be included in the articles. No doubt, A\&I Services as well as citation databases enforce the inclusion of these features for further bibliometrics analysis. The study showed that a total of 262 journals $(73 \%)$ included information on the authors' academic degree in the articles. On the other hand, 82.5 percent (296) of journals were sensitive in inserting academic rank. The majority of journals $(98.6 \%, 354)$ have a strong tendency toward author affiliations. A detailed investigation based on different subject disciplines in relation to the presence of academic profiles is presented in Table 7.

Table 7: Presence of Academic Profiles based on Subject Disciplines

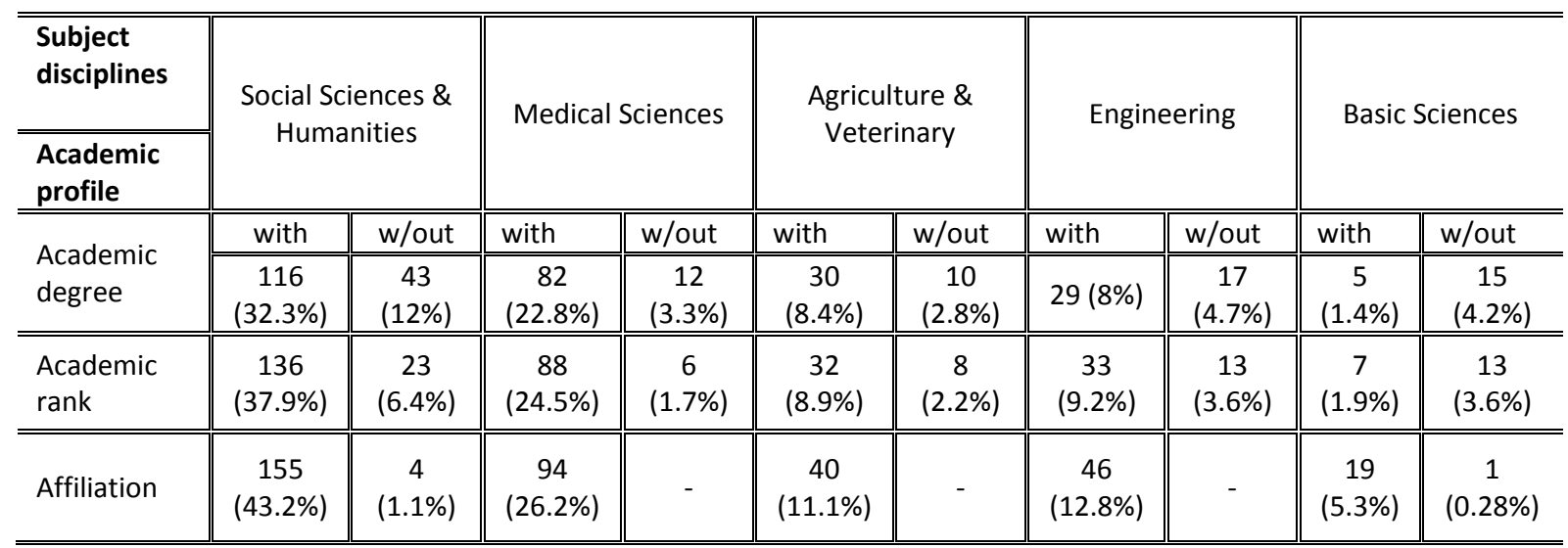




\section{Presence of Other Information or Features}

\section{a) Year of First Publication}

Since all journals sampled indicated their year of first publication, it was possible to determine the age of publication for these journals. A total of 109 journals (30.36\%) have a publication history of more than 15 years; 157 journals (43.74\%) are about $4-11$ years; and about 14 percent (48) of journals are less than three years of age. A detailed investigation based on different subject disciplines in relation to the journals' age is presented in Table 8.

Table 8: Journals' Age based on Subject Disciplines

\begin{tabular}{|c|c|c|c|c|c|c|c|c|c|c|}
\hline \multirow{2}{*}{$\begin{array}{l}\begin{array}{l}\text { Subject } \\
\text { disciplines }\end{array} \\
\text { Journals' age }\end{array}$} & \multicolumn{2}{|c|}{$\begin{array}{c}\text { Social } \\
\text { Sciences \& } \\
\text { Humanities }\end{array}$} & \multicolumn{2}{|c|}{$\begin{array}{l}\text { Medical } \\
\text { Sciences }\end{array}$} & \multicolumn{2}{|c|}{$\begin{array}{c}\text { Agriculture \& } \\
\text { Veterinary }\end{array}$} & \multicolumn{2}{|c|}{ Engineering } & \multicolumn{2}{|c|}{ Basic Sciences } \\
\hline & Freq. & $\%$ & Freq. & $\%$ & Freq. & $\%$ & Freq. & $\%$ & Freq. & $\%$ \\
\hline 1-3 years & 23 & 14.5 & 5 & 5.3 & 6 & 15 & 10 & 21.8 & 4 & 20.0 \\
\hline 4-7 years & 43 & 27.0 & 20 & 21.3 & 7 & 17.5 & 14 & 30.4 & 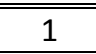 & 5.0 \\
\hline 8-11 years & 32 & 20.0 & 23 & 24.5 & 6 & 15.0 & 6 & 13.0 & 5 & 25.0 \\
\hline $12-15$ years & 21 & 13.2 & 19 & 20.2 & 2 & 5.0 & 1 & 2.2 & 2 & 10.0 \\
\hline $15^{+}$ & 40 & 25.2 & 27 & 28.7 & 19 & 47.5 & 15 & 32.6 & 8 & 40.0 \\
\hline Total & 159 & 100 & 94 & 100 & 40 & 100 & 46 & 100 & 20 & 100.0 \\
\hline
\end{tabular}

\section{b) Editorials}

The idea or opinion piece, as well as journal's issue scope and coverage are written in editorials. Unfortunately, 274 (76.3\%) journals disregarded the editorials. Table 9 details this finding based on the journals' subject disciplines.

Table 9: Presence of Editorials based on Subject Disciplines

\begin{tabular}{l||c|c||c|c||c||c}
\hline \hline \multirow{2}{*}{\multicolumn{1}{c||}{ Subject Disciplines }} & \multicolumn{2}{c||}{ Freq. } & \multicolumn{2}{c||}{ \% within groups } & \multicolumn{2}{c}{ \% between groups } \\
\cline { 2 - 7 } & with & w/out & with & w/out & with & w/out \\
\hline \hline Social Sciences \& Humanities & 114 & 45 & 71.7 & 28.3 & 31.8 & 12.5 \\
\hline \hline Medical Sciences & 74 & 20 & 78.7 & 21.3 & 20.6 & 5.6 \\
\hline \hline Agriculture \& Veterinary & 38 & 2 & 95.0 & 5.0 & 10.6 & 0.56 \\
\hline \hline Engineering & 33 & 13 & 71.7 & 28.3 & 9.2 & 3.6 \\
\hline \hline Basic Sciences & 15 & 5 & 75.0 & 25.0 & 4.2 & 1.4 \\
\hline \hline
\end{tabular}

\section{c) Receipt and Acceptance Date}

Authors are concerned about the duration of journal peer review process. The length of time between manuscript submission and acceptance is important for the journal contributors. Disclosing to reader about this time lag would help them to decide where to publish their scientific works. This study indicated that about 70 percent (251) of titles emphasized on recording the date received and acceptance in the articles. Table 10 presents this finding. 
Table 10: Recording the Date Received and Acceptance in the Articles based on Subject Disciplines

\begin{tabular}{l|c|c||c||c||c||c}
\hline \hline \multirow{2}{*}{\multicolumn{1}{c|}{ Subject Disciplines }} & \multicolumn{2}{c||}{ Freq. } & \multicolumn{2}{c||}{ \% within groups } & \multicolumn{2}{c}{ \% between groups } \\
\cline { 2 - 7 } & with & w/out & with & w/out & with & w/out \\
\hline \hline Social Sciences \& Humanities & 102 & 57 & 64.2 & 35.8 & 28.4 & 15.9 \\
\hline \hline Medical Sciences & 84 & 10 & 89.4 & 10.6 & 23.4 & 2.8 \\
\hline \hline Agriculture \& Veterinary & 31 & 9 & 77.5 & 22.5 & 8.6 & 2.5 \\
\hline \hline Engineering & 20 & 26 & 43.5 & 56.5 & 5.6 & 7.2 \\
\hline \hline Basic Sciences & 14 & 6 & 70.0 & 30.0 & 3.9 & 1.7 \\
\hline \hline
\end{tabular}

\section{d) Abstracts and Keywords}

Abstracts and keywords play an immense role in digging out the relevant published materials, since the words act as "keys" to unlock the desired scientific paper full articles from a vast collection of related publications. To improve the retrieval and visibility of Persian journals on the Web, the title of article, authors' affiliations, abstracts and keywords are translated from Persian into English. Findings showed that 254 journals (70.8\%) and 333 journals (92.8\%) included English-language abstracts and keywords in their articles respectively. The breakdowns of the numbers and percentage of journal information translated into English are shown in Table 12. Further analysis based on Chi Square Test indicated that journals are more concerned about the translation of keywords and academic degree to English compared to information about authors' affiliation, academic rank and qualification (Table 12).

Table 11: Information Translated from Persian into English

\begin{tabular}{l|c|c||c|c}
\hline \hline \multirow{2}{*}{\multicolumn{1}{c||}{ Information }} & \multicolumn{2}{c|}{ Freq. } & \multicolumn{2}{c}{$\%$} \\
\cline { 2 - 5 } & with & w/out & with & w/out \\
\hline \hline Abstract & 254 & 105 & 70.8 & 29.2 \\
\hline \hline Academic rank & 251 & 108 & 69.9 & 30.1 \\
\hline \hline Academic degree & 349 & 10 & 97.2 & 2.8 \\
\hline \hline Affiliation & 205 & 154 & 57.1 & 42.9 \\
\hline \hline Keywords & 333 & 26 & 92.8 & 7.2 \\
\hline \hline
\end{tabular}

Table 11: Chi Square Test for Association between all Subject areas and Translation of Information into English

\begin{tabular}{c|c|c|c|c|c}
\hline \hline Information & Abstract & $\begin{array}{c}\text { Academic } \\
\text { rank }\end{array}$ & $\begin{array}{c}\text { Academic } \\
\text { degree }\end{array}$ & Affiliation & Keywords \\
\hline \hline All subject & $61.841^{\mathrm{a}}$ & $\begin{array}{c}56.961^{\mathrm{a}} \\
\text { disciplines }\end{array}$ & $\begin{array}{c}320.114^{\mathrm{a}} \\
\text { Sig. }=0.000\end{array}$ & $\begin{array}{c}7.254^{\mathrm{a}} \\
\text { Sig. }=0.000\end{array}$ & $\begin{array}{c}262.562^{\mathrm{a}} \\
\text { Sig. }=0.000\end{array}$ \\
\hline \hline
\end{tabular}

a. 0 cells $(50 \%)$ have expected frequencies less than $5 .(\mathrm{df}=1, \mathrm{P} \leq 0.05)$ 


\section{DISCUSSIONS}

Many factors are taken into account when evaluating journals for coverage in Abstracting and indexing services as well as citation databases, and based on the basic publishing standard and editorial content, editors are able to determine the journal's overall structural strengths and weaknesses, and guide them towards standardization. Since being indexed in online A\&I services is the target of journals, deviation from standards and criteria may lead to failure in journal visibility in the digital environment and results in fewer readerships. Thus, monitoring journals in keeping standards will guarantee the quality and influence of the journals.

Journal publication frequency has a correlation with journal impact factor (Liu, Liu and Wang 2012). Besides the publication frequency, the timeliness of publication is one of the criteria of A\&I services' and citation systems' journal selection policy for coverage. The ability to publish on time implies a healthy backlog of manuscripts essential for ongoing viability (Testa 2016). This is an indication of journal quality. Globally, most journals are published quarterly, followed by monthly and bimonthly. This study also showed that the majority of the Iranian journals sampled are published quarterly. However in Iran, there are more journals published biannually compared to bimonthly.

Introduction to the editorial board members is of importance to the readers. The inclusion of editor-in-chief, managing editor and editorial boards with their contact information facilitates the mutual relationships between authors and editors, and will determine if the journal is able to attract established scholars in the field of study. On the other hand, the academic information of well-established editors and their reputation in the respective field are the indication of the importance of review process for the journal as well as the assurance of quality control (Hill 2008). The results of the study showed that majority of the Persian journals (more than 90\%) were bounded to the aforementioned elements.

It is a fact that Iranian scientific journals are in transition from print to fully electronic. At present, the majority of them are in the form of hybrid journals. One of the most important reasons behind this fact is that these journals are mainly published by universities, research institutes and academic associations. These for-non-profit publishers are influenced and evaluated by MSRT and MOHE, and their committee based on a variety of standards and assessment criteria. Therefore, from financial and administrative points of view Iranian journals are mainly supported and ruled by governmental budgets and policies. There is still an inclination towards print format in journals assessment exercise in Iran, however there has been strong tendency to move towards having online presence.

Layout quality is an element considered in this study. A good number (98.3\%) of journals sustained the layout consistency. These journals develop a house style and attempt to keep a visual composition consistency for each issue. Editors should be sensitive to customize the design of the pages to suit the audience based on journal publication template. Academic copy editing seeks to ensure that an article conforms to the journal's house style, that all of the referencing and labelling is correct, and that the text is consistent and legible; and often this work involves substantive editing and negotiating with the authors. In this process the regulation of the journal layout provides the unity of journal envisaged by the authors, as well as readers. Despite the importance of consistency in terms of information on volume and issue, this was less considered in the current study.

This study has identified a few exclusive features of journal quality present in Iranian journals. General guidelines, multiple authorship, manuscript submission, and peer review process were well-developed. The results uncovered that Iranian journal editors are 
concerned about instructions to authors ( $94.2 \%$ of journals). Diversity in the contributors is also a matter of importance to journals $(92.8 \%$ of articles are authored by multiple authors). This is also the indication of the vast geographical distribution of the journals among established scholars in various fields of study.

Another important feature that should be considered in relation to journal articles is "editorial" section. When one has been asked to write an editorial for an academic journal, she/he should have ability to interpret the issues and ensure that the readers benefit from the discussion. Discussing specialized areas of immediate importance to the research community indicate editorial awareness and knowledge on a given subject. The results showed that 76.3 percent of journals (274 titles) disregarded inclusion of editorials. Inclusion of editorials is an issue that every editor, editorial board member, journal and its policy makers should decide for themselves and their respective publications. To that extent it is individual, and some may consider it the internal matter of the publication (Singh and Singh 2006).

Scholarly communication network is reinforced through the presence of academic profiles in the articles. Author affiliation exerts the relations in a specific field and is a useful tool for assessing higher education institutes in citation analysis and ranking systems. On the other hand, it provides inter and intra scientific collaboration at the meso and macro level. This study reported an overwhelming majority of journals are concerned about author affiliations (354 titles, 98.6\%). Academic degree and rank are elements for further analysis of journal usage, especially in citation analysis.

Publishing in scholarly peer reviewed journals usually entails long delays from submission to publication. Presence of information on date receipt and acceptance in articles provides the journal-centric view of speed of publication, in particular at the delay from submission to acceptance and the delay from acceptance to final publication, as well as the total delay time. This study showed that 251 journal titles (69.9\%) indicated each manuscript's receipt and acceptance date. In general the length of time between a manuscript submission and acceptance is 7 months. The length of time between manuscript receipt and acceptance plays a crucial role in researchers' access to the latest findings of peers (Bornmann and Daniel 2010). The delays slow the dissemination of scholarship and can provide a significant burden on the academic careers of authors (Björk and Solomon 2013).

\section{CONCLUSION}

The main stakeholders of scholarly communication are the contributors, readers, and distributors. There is a keen relationship in the chains of three stakeholders in the scholarly communication lifecycle. It has been more than three centuries that scholarly journals introduce and present scientific research and attempt to ensure that articles meet the journal's standards of quality, and scientific validity. From the beginning, scholarly journals focused on quality control and to support this premise they should follow standard convention. Relative to quality control, verifying journals features is of great importance. Unconformity of the features discussed in this study would undoubtedly causes loss of journal quality and is not an acceptable performance from the scientific community perspective. The significant point is that on the digital environment ignoring each studied features would affect the manuscript visibility, access, readership, and research impact. 


\section{ACKNOWLEDGEMENT}

This research received no specific grant from any funding agency in the public, commercial, or not-for-profit sectors.

\section{REFERENCES}

Abrizah, A., Zainab, A.N., Edzan, N.N. and Koh, A.P. 2013. Citation performance of Malaysian scholarly journals in the Web of Science, 2006-2010. Serials Review, Vol. 39, no. 1: 47-55.

Ackermann, E. 2006. . Indicators of failed information epidemics in the scientific journal literature: A publication analysis of Polywater and Cold Nuclear Fusion. Scientometrics, Vol. 66, no. 3:451-466.

Ball, P. 2008. A longer paper gathers more citations. Nature, Vol. 455, 274-275.

Björk, B.C. and Solomon, D. 2013. The publishing delay in scholarly peer-reviewed journals. Journal of Informetrics, Vol. 7, no. 4: 913-923.

Bordons, M. and Gómez, I. 2004. Towards a single language in science? A Spanish view. Serials, Vol. 17, no. 2: 189-195.

Bornmann, L. and Daniel, H.D. 2010. How long is the peer review process for journal manuscripts? A case study on Angewandte Chemie International Edition. Chimia, Vol. 64, no. 1/2: 72-77.

Committee on Publication Ethics, COPE. 2011. Code of conduct and best practice guidelines for journal editors. Available at: http://publicationethics.org/resources/ guidelines.

Falagas, M.E., Zarkali, A., Karageorgopoulos, D.E., Bardakas, V. and Mavros, M.N. 2013. The impact of article length on the number of future citations: A bibliometric analysis of general medicine journals. PLOS One, Vol. 8, No. 2: e49476. Available at: http://www.ncbi.nlm.nih.gov/pmc/articles/PMC3566179/.

Graf, C., Wager, E., Bowman, A., Fiack, S., Scott-Lichter, D., \& Robinson, A. 2007. Best practice guidelines on publication ethics: A publisher's perspective. International Journal of Clinical Practice, Vol. 61, no. 152: 1-26. Available at: http://dx.doi.10.1111/j.1742-1241.2006.01230.x

Hill, M. 2008. The E-Resources management handbook: The editorial board. Oxford University Press. Available at: http://www.uksg.org/sites/uksg.org/files/20-HillM480867626876184.pdf.

International Committee of Medical Journal Editors, ICMJE. 2014. Recommendations for the conduct, reporting, editing, and publication of scholarly work in medical journals. Available at: http://www.icmje.org/recommendations/.

Liu, L. X., Liu, R. Y. and Wang, M.Y. 2012. Correlation of publication frequency with impact factors in 1058 medical journals in SCl-expanded database. Malaysian Journal of Library \& Information Science, Vol. 17, no. 3: 7-16.

Mavros, M., Bardakas, V., Rafailidis, P., Sardi, T. and Demetriou, E. 2013. Comparison of number of citations to full original articles versus brief reports. Scientometrics, Vol. 94, no. 1: 203-206

MEDLINE ${ }^{\circledR}$ Journal Selection Fact Sheet. 2014. Available at: http://www.nlm.nih.gov/ pubs/factsheets/jsel.html.

O'Moore-Klopf, K. 2010. Summary of the North American ISMTE Conference, International Society of Managing and Technical Editors. Vol. 3, no. 8. Available at: http://c.ymcdn.com/sites/www.ismte.org/resource/resmgr/conference_material/201 0_na_summary.pdf 
Priem J. and Hemminger B. M. 2012. Decoupling the scholarly journal. Frontiers in Computational Neuroscience, Vol. 6, no. 19. Doi: 10.3389/fncom.2012.00019

Public Knowledge Project, PKP. 2015. Module 10: Journal visibility II: Getting indexed: Unit 2: Why you need to be included. Available at: http://pkpschool.sfu.ca/becoming-aneditor/module-10/.

Sharma, K.K. and Mediratta, P.K. 2002. Importance of Keywords for retrieval relevant articles in Medline search. Indian Journal of Pharmacology, Vol. 34 no. 5: 31-43.

Singh A. and Singh S. 2006. What Is A Good Editorial? (Editorial). In: What medicine means to me. Mens Sana Monograph, Vol. 4, no. 1. Available at: http://www.ncbi.nlm.nih.gov/pmc/articles/PMC3190447/.

Sotudeh, H., Razmjoo, F. and Zare, L. 2009. The Evaluation of the visibility of Iranian scholarly journals on the Internet based on international standards: with an emphasis on features affecting the visibility. Journal of Library and Information Science, Vol. 12 no. 4: 205-228. (in Persian).

Testa, J. 2016. The Thomson Reuters journal selection process. Web of Science, Thomson Reuters. Available at: http://wokinfo.com/essays/journal-selection-process/

Yang, C.W. 2014. The Korean Journal of Internal Medicine's long road to being listed in the Science Citation Index Expanded. Science Editing, Vol.1 no.2: 118-121. Available at: http://dx.doi.org/10.6087/kcse.2014.1.118.

Wager, E. and Kleinert, S. 2011. Responsible research publication: international standards for authors. A position statement developed at the 2 nd World Conference on Research Integrity, Singapore, July 22-24, 2010. Chapter 50 in: Mayer T \& Steneck N (eds) Promoting Research Integrity in a Global Environment. Imperial College Press / World Scientific Publishing, Singapore (pp 309-16).

Wikipedia. 2015. List of languages by number of native speakers. Available at: http://en.wikipedia.org/wiki/List_of_languages_by_number_of_native_speakers.

Xue-Li, L., Rui-Yuan, L. and Mei-Ying, W. 2012. Correlation of publication frequency with impact factors in 1058 medical journals in $\mathrm{SCl}$-expanded databases. Malaysian Journal of Library and Information Science, Vol. 17 no. 3: 7-16. 